\title{
Traumatic Thoracic Duct Transection managed with Left Thoracoscopy: A Case Report and Review of Literature
}

\author{
Eduardo Smith-Singares, Abdul Saied
}

\section{ABSTRACT}

Context: Chylothorax is an uncommon complication after penetrating trauma to the chest and the neck. Only $25 \%$ of all chylothorax cases are related to penetrating trauma. We report such a case on a transmediastinal stab wound, managed by video-assisted thoracic surgery.

Case report: A 48-year-old male presented to our level I trauma center after sustaining a stab wound to the right chest. Initial workup revealed a left side pneumothorax. After chest tube placement $700 \mathrm{ml}$ of blood and milky fluid were recovered. The patient was managed initially with TPN, without success. On day 3, he was taken to the OR for a left VATS. The thoracic duct was dissected and the injury identified and controlled with hemoclips. The intervention was successful and the patient was discharged on POD \#4.

Discussion: Chylothorax are classified and managed according to the daily output of the fistula. While low output chylothorax are more frequent, more likely related to malignancy of the mediastinum and lymph nodes, and more likely to close with nonsurgical management; traumatic chylothorax are generally high output and more likely to require surgical intervention. The different approaches to this difficult pathology are reviewed.

Keywords: Chylothorax, Thoracoscopy, Thoracic duct ligation, Transmediastinal stab.

How to cite this article: Smith-Singares E, Saied A. Traumatic Thoracic Duct Transection managed with Left Thoracoscopy: A Case Report and Review of Literature. Panam J Trauma Critical Care Emerg Surg 2013;2(2):97-99.

Source of support: $\mathrm{Nil}$

Conflict of interest: None declared

\section{RESUMEN}

Contexto: Quilotórax es una rara complicación del trauma toraco-cervical penetrante. Solo el $25 \%$ de todos los casos de Quilotórax estan relacionados con trauma penetrante. A continuación presentamos un reporte en una víctima de herida punzante transmediastínica, manejada con Toracoscopía.

Reporte del Caso: Un paciente masculino de 48 años fue transportado a nuestra unidad de traumatología con una herida punzo-cortante en el hemitórax derecho. La evaluación inicial mostró un neumotórax izquierdo, que fue manejado con un tubo de toracostomía, drenando $700 \mathrm{ml}$ de sangre y un líquido blanco-lechoso en apariencia. Nutrición Parenteral Total no pudo controlar la fístula, y en el tercer día el paciente fue intervenido. El ducto toraccico fue disecado usando toracoscopía, y sellado con Hemoclips. El paciente tolero la operación y fue dado de alta en el día 4 postoperatorio.

Discusión: El Quilotórax se clasifica segun el gasto de la fístula linfática. Los casos de bajo gasto son mas frecuentes, relacionados con neoplasias del mediastino y nodulos linfáticos y tienen una mayor probabilidad de cerrar con manejo médico expectante. Los casos relacionados con trauma tienen generalmente un gasto elevado y requieren manejo quirúrgico. Se discutirán las diferentes alternativas de manejo.

Palabras claves: Quilotórax, Toracoscopía, Ligación del Ducto Toracico, Herida Punzo-Cortante Transmediastínica.

\section{CASE REPORT}

A 48-year-old male patient arrived as a trauma activation to our level I trauma center after sustaining a single stab wound in the right parasternal area, $4 \mathrm{~cm}$ in length, located $2 \mathrm{~cm}$ below the right clavicle. His primary survey was positive for decreased breath sounds on the left hemithorax. His carotid and brachial pulses were palpable and equal on both sides. His GCS was 15 . A single view AP chest X-ray was obtained in the trauma bay, that showed a $15 \%$ pneumothorax on the left side. The rest of his physical examination showed no additional injuries. A thoracostomy tube was placed, obtaining approximately $700 \mathrm{ml}$ of a mixture of blood and a milky fluid. The rest of his workup included a CT angio of the chest (that showed a resolved pneumothorax with no vascular injuries), an esophagogram (normal), and a 2D echo (negative).

The patient was initially admitted to the trauma floor, made NPO and started on TPN. During the next 48 hours the output of the tube slowly decreased and changed to transparent, however, a PO challenge brought back the milky appearance and nearly doubled the volume over a short period of time. Therefore a decision was made to proceed with operative intervention. The selected approach was a left side thoracoscopy.

Just after the induction of anesthesia and prior to positioning the patient, an enteral feeding tube was placed in a far postpyloric position with the aid of an EGD scope. Then $100 \mathrm{ml}$ of heavy whipping cream (WhiteWave Horizon Organic, Broomfield Co) was bolused by the anesthesia team. During the left VATS an injury was observed in the mediastinum just behind the takeoff of the left subclavian artery (Fig. 1), where active extravasation of milky chyle was pooling. Dissection was performed until the proximal and distal ends of the severed, thoracic duct were visualized (Fig. 2). They were secured by hemoclips (Ethicon Endosurgery Inc, Cincinnati, OH). A lung injury was also observed in the upper lobe, that appeared pneumostatic and was left untreated. Finally a supplemental mechanical pleurodesis was performed and two chest drains were left. 


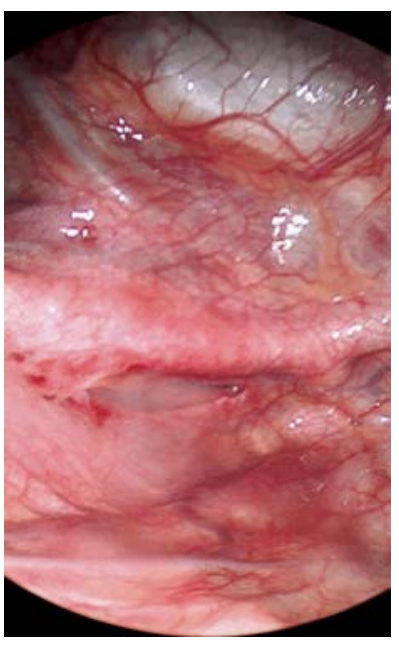

Fig. 1: Mediastinal injury, just behind the left subclavian artery, pooling chyle

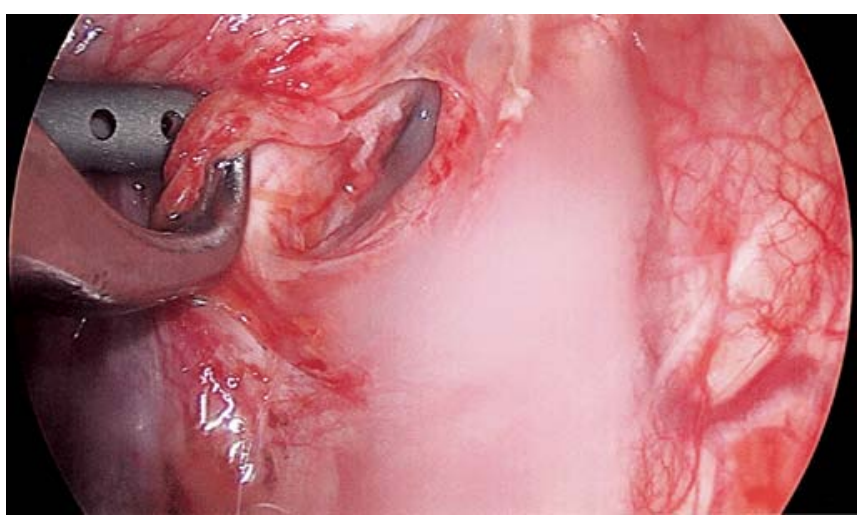

Fig. 2: Dissected thoracic duct, severed (distal end showed). Chyle could be seen pooling in the pleural cavity and in the mediastinum

Upon lung ressuflation no air leak was observed in the system, and no chyle was observed again in the drains.

A regular diet was tolerated immediately postoperative, and all drains were placed on water seal after 8 hours of suction, and mobilized within 48 hours. On POD \#4, with the patient tolerating a regular diet and all chest drains removed he was discharged home. The patient presented back on POD \#6 with abdominal pain and distention. The chest X-ray showed no residual pneumo or hydrothorax, and the mediastinal clips appeared in good position. The abdominal X-rays showed air-fluid levels and uniform small bowel distention consistent with an ileus. The patient was made NPO and a nasogastric tube inserted. The next day he experienced a bowel movement and was able to pass flatus. The NG tube was removed and the diet advanced, and he was discharged again the next day on POD \#8. On last follow-up (6 months after the injury), the patient is asymptomatic and thriving.

\section{DISCUSSION}

Chylothorax was first described in 1633 by Bartolet, in basis of its appearance. Currently, it is defined as the accumulation of fluid in the pleural cavity that when analyzed with lipoprotein electrophoresis exhibits a content greater than $4 \%$ of chylomicrons. ${ }^{1}$ In a study performed 30 years ago by Staats et al, ${ }^{2}$ it was shown that all pleural effusions with a triglyceride content (a surrogate marker) over $110 \mathrm{mg} / \mathrm{dl}$ proven to be chylous, and since this is a much quicker and simpler assay to perform, it has replaced in clinical practice the lipoprotein electrophoresis. Chyle usually has a milky appearance, but it can turn into watery clear in the absence of oral intake or severe malnutrition.

The first traumatic instance of chylothorax was described by $\mathrm{H}$ Quincke in $1875 .{ }^{3}$ Since, then several other reports have been made, more commonly with penetrating trauma. A high index of suspicion is required when confronted with nonmilky type pleural effusions in blunt trauma patients, since the failure to treat could lead to severe nutritional consequences: Calculations show that the average patient losing 1 liter (L) of chyle/day would lose $420 \mathrm{gm}$ of fat and 420 gm of protein within 1 week. ${ }^{4}$ It can also cause metabolic acidosis and other electrolyte disturbances, lymphopenia and (due to the high fibrinogen content of chyle) coagulopathy.

Treatment is based on the amount of the fistulous output, as high ( $1 l$ per day or more) or low. Low output are more likely $(50-60 \%)$ to close with expectant (i.e. nonsurgical) management, ${ }^{5}$ such as tube thoracostomy, a low fat diet, medium chain fatty acids, low protein diets or the use of TPN. Octreotide (which decreases triglycerides absorption) has proven some value to accelerate closure and prevent some of the morbidity of the chyle loss. Surgical treatment has been consistently showed to carry better outcomes ${ }^{6}$ and its required in high output fistulas. It should be ideally performed within the first 5 days of the injury. Other alternatives to thoracotomy include embolization of the thoracic duct ${ }^{7}$ and minimally invasive options, such as VATS. Pleurodesis is a required part of the operation.

Interestingly, our patient developed ileus upon ligation of the thoracic duct. This complication has not been reported before. It could represent a milder manifestation of lymphatic ectasia, the cause of the more common (but still rare) chylous ascites after thoracic duct occlusion. More studies would be required to ascertain that hypothesis. On follow-up, this patient did not developed nutritional deficiencies, chylous ascites or lymphedema, probably due to the development of collateral channels in his lymphatic circulation.

\section{REFERENCES}

1. Maldonado F, Hawkins FJ, Daniels CE, et al. Pleural fluid characteristics of chylothorax. Mayo Clin Proc 2009 Feb; 84(2): 129-133.

2. Staats BA, Ellefson RD, Budahn LL, Dines DE, Prakash UB, Offord K. The lipoprotein profile of chylous and nonchylous pleural effusions. Mayo Clin Proc 1980;55(11):700-704.

3. Seitelman E, Arellano JJ, Takabe K, et al. Chylothorax after blunt trauma. J Thorac Dis 2012 June 1;4(3):327-330. 
4. Cardillo K. Nutrition interventions for chylous effusions. Support Line 2001;23:18-23.

5. Marts BC, Naunheim K, Fiore AC, Pennington DG. Conservative versus surgical management of chylothorax. Am J Surg 1992; 164:532-534.

6. Haniuda M, Nishimura H, Kobayashi O, et al. Management of chylothorax after pulmonary resection. J Am Coll Surg 1995;180: 537-540.

7. Patel N, Lewandowski RJ, Bove M, et al. Thoracic duct embolization: a new treatment for massive leak after neck dissection. Laryngoscope 2008;118:680-683.

\section{ABOUT THE AUTHORS}

\section{Eduardo Smith-Singares (Corresponding Author)}

Surgeon, Department of Surgery, Advocate Christ Medical Center, IL USA, e-mail: eduarsmith@gmail.com

\section{Abdul Saied}

Resident Physician, Department of Surgery, University of Illinois IL, USA 